\title{
Jacob Riis and Double Consciousness: The Documentary/Ethnic "I" in How the Other Half Lives
}

\section{Bill Hug Jacksonville State University}

"Contradictory" is the watchword in scholarship on Danish-American photojournalist Jacob Riis. "Wildly contradictory, morally schizophrenic": so Keith Gandal describes Riis' work (18). “A deeply contradictory figure [...] a conservative activist and a skillful entertainer who presented controversial ideas in a compelling but ultimately comforting manner": such is the assessment of Riis offered by Bonnie Yochelson and Daniel Czitrom (xv). "The typical Victorian moralist," but also the Progressive-so Tom Buk-Swienty proclaims him (239, XIII).

These assertions point up perhaps the central issue in the relatively small amount of scholarly work on Riis since his rediscovery by Alexander Alland in 1947. How does one resolve the contradictions, in his photos and texts, between protest of the plight of the ethnic urban poor and acceptance of pejorative nativist assumptions about them? Until the 1980s, scholars usually did so by emphasizing the apparent haziness of Riis' thought. 
According to Roy Lubove in The Progressives and the Slums, Riis' social theorizing was "unsystematic[...] almost impressionistic"(49); Charles Madison, editor of the 1970 Dover edition of How the Other Half Lives, calls Riis' sociological thought "relatively unsophisticated and[...] limited"(vii). To these scholars, Riis seems oblivious to the conflicting portrayals of the poor in his works.

Recent commentators have sometimes been harsher, seeing the tensions as reflections of Riis' systematic efforts to project himself as spokesperson for the emerging American middle class. Scholars such as Maren Stange, Sally Stein, and Gandal regard Riis' work as canny exercises in definition by opposition: by portraying the ethnic tenement dwellers from the smugly condescending standpoint of the American middle class, the writer affirms their status, authority, and Christian charity, and-most importantly--his own affiliation with them. For Maren Stange, Riis is the "consummate publicist" for the American bourgeoisie, eager to ally himself with them (5). Sally Stein is more blunt, portraying Riis as "one of a long succession of professional informers manufacturing vast amounts and kinds of information [about the urban poor] to assuage and intensify [middle class] fantasies" (10). Gandal's conception of Riis presents a variation on this theme. He describes Riis' social vision as the mixture of two opposed but complementary ethical approaches: one, the traditional Protestant commitment to moral principle maintained through discipline (personal as well as institutional); the other, a modern, technology-andmedia-based promotion of "spectacle," the American public's emerging preoccupation with looking at others and being looked at themselves. In other words, tenement dwellers' eagerness to be seen, reflected in their frequent desire to be photographed, might well be employed to promote their own moral development. While this conception of Riis treats his contradictions in more sophisticated and perhaps more plausible ways 
than do those of Stange or Stein, Gandal still perceives Riis in essentially the same fashion as these other scholars--as a writer eager to promote the middle class and his membership of it. If earlier commentary portrays Riis as a naif, unaware of his own contradictions, these contemporary scholars depict him as a bourgeois assimilationist.

While both approaches offer important information, both represent Riis in terms that are rather simple and narrow intellectually, psychologically, and, above all, rhetorically; terms that do not account adequately for the individual and his work. Perhaps the major flaw in both is the overly simple reading of the "I" who speaks for Riis throughout his works. Proponents of both conceptions assume that Riis, in all his first-person commentary on the tenement poor, is oblivious to the ambiguities in his own self-portrayal. From this perspective, Riis' narrative "I" lacks any capacity for self-detachment: his "I" speaks merely as Jacob Riis, in an ingenuous fashion free of conscious artifice, dissimulation, ambiguity, and, certainly, of irony. Whatever tensions or oppositions scholars find are explained as products of his sloppy thinking or of his panderings to the middle class. So, when this "I" speaks of himself and his polite audience as "we" in contrast to the "they" of "the other half," both sides assume that Riis allies himself consistently and whole-heartedly with his audience.

Yet this premise may itself be ingenuous, for several reasons. For one thing, the documentary context from which Riis" "I" addresses us--a context which, as William Stott has noted, Other Half was instrumental in establishing (30)--operates through the conscious interplay of tensions and contradictions. Stott points out that "documentary," as idea and as genre, melds two opposing meanings:

The first, the dictionary meaning, we use when we speak of 'documentary proof' and 'legal documents,' of 'documentary history' and 'historical documents.' 
This 'documentary' has been defined as 'presenting facts objectively and without editorializing and inserting fictional matter [...].'(5-6)

This first type of "document" Stott terms "official." In opposition to it, though often combined with it, is the "human" document. This latter sort "is not objective," notes Stott, " but thoroughly personal," for the human document "carries and communicates feeling, the raw material of drama" (6-7). The most powerful documentaries combine the two meanings, rousing "human" feeling via "official" detachment.

Assuming that Riis understood, to at least some extent, these ambiguities implicit in the documentary genre he helped originate, he must also have realized that they could be most effectively employed in the narrative voice, the "I" whom Riis creates to carry us through the tenements of New York City and to offer commentary. ${ }^{1}$ If this "I" is not simply the sloppily thinking Progressive or the middle class assimilationist scholars have perceived, then exactly who is he? Whom does he represent, and how he does he regard his subject and his audience? The answers to these questions require an examination of the relations between documentary and autobiography in Other Half, for the "l" who addresses us does so from both contexts, though the documentary context is the more apparent. But by embedding his autobiographical "l" within the documentary context, Riis may actually be freer to manipulate his self-portrayal than authorial personae in conventional autobiographies.

All involved will agree the speaker is some species of the author himself. In taking us on guided tours of various tenement districts and offering firsthand accounts of his own tenement experiences, this narrative "I" repeatedly indicates that the pronoun refers to Jacob Riis, police reporter. If the author's conscious intention is, through his narrative voice, to meld "documentary proof" with "human" feeling, the feelings he wishes to rouse inevitably have their origins in himself-in his own 
experiences and his thoughts and feelings about them. In other words, to understand most fully the "documentary" tensions and contradictions of the "I" who addresses us in Other Half, we must approach this speaker as an autobiographical "I," as a particular rendering of Riis himself, and consider his manipulations of self-portrayal from that angle.

By the time Riis published Other Half, in 1890, he had acquired firsthand a profound understanding of ethnic relations in late $19^{\text {th }}$ century America. When the young Dane had arrived, in 1870, newcomers were entering the country in numbers unprecedented-ten million between 1860 and 1890 (Jones 179). Response to these "aliens" was becoming more and more hostile; as Roy Lubove has noted, nativism in later $19^{\text {th }}$ century America was "pervasive" (61). A nativist frenzy erupted after Chicago's Haymarket riots; Slavic strikebreakers in the Pennsylvania coalfields were shot by state militia; in New Orleans, eleven Italians accused of killing a police superintendent were lynched; New York and Pennsylvania excluded all immigrants from employment in state and local public works; Idaho prohibited private corporations from hiring any "alien" who would not declare his intention to become an American citizen (Higham 87-97, Jones 177-229).

Twenty years' immersion in this ethnic maelstrom would make Riis a savvy and sensitive commentator on the immigrant's plight. Like many newcomers, he spent his first years in America eking out a hand-tomouth existence, taking whatever work he could findcarpentering, hoeing cucumbers, peddling books and flatirons. When there was no work, he starved, and found sleeping quarters wherever he could-in doorways, the police station lodging house, even a churchyard. As Riis' autobiography, The Making of an American, amply reveals, the young Dane repeatedly faced the prejudice and ill treatment so many immigrants encountered: the spoiled meat given to Riis and the other passengers in steerage on the voyage over; the policeman who uses 
his boot and nightstick to roust the sleeping Riis from a Chatham Square doorway throughout his first winter in America; another policeman who throws him out of a police station lodging house for reporting a theft; the mill foreman who twice reduces Riis' pay for planing doors too quickly - "he did not want his men to make over $\$ 10$ [sic] a week, he said; it was not good for them"-the "Yankee businessman" who refuses to invest in Riis' scheme for devices called "window reflectors," then produces them himself (American 40-102). Even after landing the reporting job with the New York Tribune, Riis, the immigrant, was still subjected to nativist bias. Reporters from the other New York papers immediately labeled him "the Dutchman" and joined forces to keep him from getting stories. As Riis recalls, “[t]hey hailed the coming of 'the Dutchman' with shouts of derision and decided [...] to finish me off while I was new" (American 200). From these experiences and many others described in Riis' autobiography, he learned how harsh the New World could be to its newcomers. In the process, the Dane also discovered the flimsiness of his own ethnic biases and of nativist stereotypes.

Like many Danes, Riis harbored a particular dislike for Germans, because Germany had taken SchleswigHolstein from Denmark in the late 1840s. "I always walk with a chip on my shoulder," Riis would write in 1910, "for I cannot forget the Great Robbery [sic] of my childhood" (qtd. in Ware 264). But experience in America provided periodic correctives to his nationalist urges. On the trip over, when rotten meat was served to Riis and the other passengers in steerage, the young Dane found himself allied with "a big, explosive German" named Adler, a former officer of the Prussian reserves, in leading a protest. (American 40 ). After landing, the two became not only bunkmates in the Pennsylvania coalfields, but good friends. Riis recalled how, when the two were working together in the mines, a stretch of roof collapsed; Dane and German ran for the surface 
"holding each other's hands as though we were not men and miners, but frightened children in the dark" (American 46). Adler's friendship softened Riis' anti-German feeling; some months later, as a laborer in a Buffalo lumberyard, he found himself taking up for some fellow workers who were newly-arrived German immigrants exploited by their "tyrant foreman." His protests got him fired (American 90). After Riis became a reporter and lecturer, the ideas of German education theorist Friedrich Froebel became essential to his own thought; he relied heavily Froebel's kindergarten concept in promoting education of immigrant children (American 312-314). Froebel was, in Riis' words, "the great kindergartner who gave us the best legacy of the nineteenth century to its successor" (qtd. In Lubove 78). Clearly, he learned to distance himself from his ancestral anger.

If Riis was prompted to question his own "Danish" biases, he came to question and to distrust ethnic assumptions prevalent in America as well. Experience had shown him, time and again, how mistaken Americans could be about Danish immigrants; he learned that Americans could be just as mistaken about other ethnic groups. Anti-Semitic feeling ran high in the country in the late $19^{\text {th }}$ century, as many Jewish immigrants arrived, often from Eastern Europe; yet Riis established and maintained strong relations with Jewish individuals, and proclaimed as much. In his police reporting, Riis employed as his chief assistant a young Jewish journalist, Max Fischel. The two developed a strong and lasting personal relationship: to Riis, Max came to be "the image of his younger self" (Lane 70). Riis also knew and worked with Felix Adler, a particularly active member of New York City's Tenement House Commission, who was both German and Jewish. In The Making of an American, Riis makes a point of praising the "Christian" compassion embodied by Adler, the "Jew or heretic, take it whichever way you please" (247). In emphasizing Adler's “Christian” virtue, Riis calls attention to the hypocrisy and the anti-Semitism of some of the "Christians" in his audience: clearly, 
the anti-Semitic "you" whom he sarcastically addresses operates from mistaken assumptions. He memorializes his bonds to both men at the end of The Making of An American: in acknowledging the friends and fellow advocates with whom he had worked for social reform-notable activists such as Jane Addams, Lyman Abbott, and Charles Parkhurst-Riis includes Adler and Max; the latter he calls the "trusty friend of the years in Mulberry Street who never said "can't once-you always knew a way" (435). Perhaps the most telling reflection of Riis' ideas regarding anti-Semitism emerges in his comment, in American, on the Dreyfuss affair. Recalling his failed attempts to return to Europe to fight the Germans in the Franco-Prussian War, he admits that, looking back, he actually takes satisfaction in the German victory. If the French could condone such flagrant anti-Semitism as Dreyfuss suffered, they did not deserve to keep AlsaceLorraine. "The country which[...] is still capable of the Dreyfuss infamy, was not fit to hold what was its own. I am glad now that I did not go [....]" (65-66). In light of Riis' Danish hostility to Germany, this statement against anti-Semitism could scarcely be stronger.

To American prejudice against Blacks and Native Americans, he had similar reactions. Through Theodore Roosevelt, Riis developed a working relationship with Booker T. Washington; the two joined forces periodically to publicize the predicament of Black Americans. In September, 1904, Riis took Washington on a tour of New York City's East Side; the following February, Riis spent two days at Tuskegee Institute, and spoke there on the need for better living and working conditions among Black Americans (Lane 176). The plight of Native Americans was brought home to Riis through his friendship with General Ely Parker. A Tonawanda Seneca, Parker had been U. S. Grant's personal secretary during the Civil War, and later the first Native American Commissioner of Indian Affairs. By the time Riis knew him, in the 1880s and 90 s, Parker had been reduced to serving as a clerk in 
the New York City Police Department. Riis found the old man compelling, not because of his military service, but because of his identity as a Native American:

It was not General Parker, however, but Donehogawa, Chief of the Six Nations [...] that appealed to me[....] There was about him an infinite pathos, penned up there in his old age among the tenements of Mulberry Street on the pay of a second-rate clerk, that never ceased to amaze me. (American 244)

Riis' comment suggests that he associates Parker's loss of stature with the plight of Native Americans generally. Though they constituted only a small portion of the inhabitants of the New York City tenements, Ely Parker's people remained on Riis' mind; his photos of the tenement poor include that of an Iroquois, Mountain Eagle, and his family (Other Half 17).

Knowing people of color--from immigrant tenement dwellers to civic leaders of Jewish, Black, and Native American origins--describing immigrants for the respectable classes, and, of course, being an immigrant himself, Riis acquired the understanding and detachment to move beyond the pejorative stereotypes prevalent among many Americans; he saw the immigrant as an individual capable of complete humanity. Riis' comments on the findings of the New York City Tenement House Commission of 1884 reflect his own sense of the fully human status of the immigrant:

[I]n 1884, came the Tenement House Commission which first brought home to us the fact that the people living in the tenements were "better than the houses." That was a big white milestone on a dreary road. From that time on we hear of "souls" in the slums. The property end of it had held the stage up till then, and in a kind of self defence, I suppose, we had had to forget that the people there had souls. 
Because you couldn't very well count souls as chattel yielding so much income to the owner: it would not be polite toward the Lord [....]. (American 246)

Being an immigrant "soul" who had himself struggled to become "better than the houses," then watching and reporting on fellow immigrants caught up in the same struggle, Riis had learned the power that environment can exert on human character. "[W]e are creatures of environment,' he proclaimed; "a man everywhere is largely what his neighbors and children think him to be" (A Ten Years' War 1). The term "everywhere" is of particular note; it generalizes, universalizes the "we." Whether "we" are Anglo, Chinese, Irish, Jewish, Black, or Native American, "we" are largely the products of our surroundings. In Riis' ideas of character formation, heredity, including ethnicity, becomes not only a relatively insignificant factor, but a dangerous notion, since it promotes ethnocentric assumptions that produce prejudice and exploitation. Heredity is, in Riis' words, "the arch-enemy of hope and effort" (American 413).

In light of his belief in the power of environment, one understands the strong, sustained emphasis Riis gives to children in his writing and his photos; children are, after all, most susceptible to their surroundings. "The bad environment becomes the heredity of the next generation," he asserts (A Ten Years' War 1). "[T]he rescue of the children is the key to the problem of city poverty [...] a character may be formed where to reform it would be a hopeless task" (Other Half 143). Throughout his public career, Riis advocated loudly for improvements in children's formative environments: improvements in tenement design and construction, more schools, more parks and playgrounds. In 1906, he helped found The Federated Boys' Clubs of America; in 1910, he served as one of the organizers of the Boy Scouts of America, and addressed the organizers' first meeting (Lane 187).

Unfortunately, when How the Other Half Lives 
first appeared, the impact of environment on human development was not widely acknowledged. As Gandal notes:

Before the 1890s sociologists had not begun to divide racial influence from the forces of culture and environment; they had not questioned the popular Larmarckian and Spencerian ideas that acquired traits could be inherited. (154)

Thus, many Americans maintained their belief in heredity and the ethnocentric assumptions that followed from it. For them, the growing immigrant presence, particularly from Southern and Eastern European cultures, seemed to confirm these assumptions. The newcomers from Italy, Poland, and Russia appeared especially alien and distinctly inferior.

Persuading a largely hostile audience to take a sympathetic viewpoint toward the immigrant would be a daunting task-particularly for a writer who was an immigrant himself. It would require not only a sophisticated awareness of the audience---especially of its ethnic assumptions--but a refined understanding of the writer-audience dynamic and how it operates-more specifically, how it might be manipulated. Above all, the task would require the very careful handling of the speaker, the "I" addressing the audience.

Riis was introduced to the rhetorical basics of attracting and holding an audience before he entered journalism. Peddling furniture, Dickens novels and flatirons throughout New York and Pennsylvania in 1872-73 (American 101-125 ), the young immigrant learned that the salesman--like the reporter or the social activist--must appeal to an audience in terms of their own needs. Addressing consumer appetites would prepare him to speak to people's more profound need for self-validation, perhaps by (apparently) affirming the audience's belief in its superiority, by appealing to its 
humanitarian urges, or both. Another business venture furthered his rhetorical education. After dabbling briefly in newspaper work in the mid-1870s, Riis purchased a stereopticon, or magic lantern, and embarked on an advertising scheme, traveling the length of Long Island, giving "open-air exhibitions." These were comprised of "ads for Brooklyn merchants [...] cunningly interlarded with the very beautiful colored views of which I had a fine collection" (American 184). ${ }^{2}$ The experience would be crucial in sharpening Riis' understanding of the dynamic between presenter and audience. Organizing the ads and "colored views," writing the accompanying commentary, and delivering it before a group, Riis faced a complex rhetorical situation: he now had to manage images, words, and self-presentation in a public venue. The stereopticon venture "was to play an important part in the real-life work that was waiting for me," he remembered; "without the knowledge which the possession of it gave me, that work could not have been carried out as it was" (American 181).

Once he was hired by the New York Tribune, the young Dane applied and enlarged his rhetorical knowledge in a far trickier context: now the immigrant was a police reporter describing tenement immigrants for the polite classes. In defining a voice, a persona to present to middle- and upper-class American readers, Riis knew that his own ethnicity would be a prominent factor. When he sold furniture, books, and flatirons to American customers, or ran the stereopticon shows for American audiences, it had been tangential; now, his ethnicity became integral. After all, Riis himself had lived the immigrant experience of the people he described. If he wished to depict his fellow immigrants in sympathetic fashion for a largely nativist audience, he would have to be very, very careful in managing his own self-portrayal. The autobiographical "|" who spoke for Jacob Riis would have to be ambiguous, "contradictory"--a shape-shifter employing the complexities of his predicament to his 
own rhetorical advantage.

As Riis was to learn, and as recent scholars have affirmed, the possibilities for manipulation in autobiographicalwritingareconsiderable. Theautobiographical first-person narrator cannot be taken at face value, so to speak, but instead as purposeful "de-facement" as Paul de Man put it (69) or as "displacement" in the words of Sandra Adell (60). The writer of autobiography, with his or her own psychological, social, and political agendas, inevitably portrays the self with an eye to these concerns, as well as to the formal requirements of narrative and to narrator-audience relations. While it is simple and convenient to assume that the writer's life produces and determines the autobiographical account, De Man posits the reverse possibility:

can we not suggest, with equal justice, that the autobiographical project may itself produce and determine the life and that whatever the writer does is in fact governed by the[ ...] demands of selfportraiture and thus determined in all its respects by the resources of his medium? [...D]oes the referent determine the figure, or is it the other way round:is the illusion of reference not a correlation of the structure of the figure, that is to say no longer clearly and simply a referent at all but something more akin to fiction? (69)

In light of this possibility, any "I" who allegedly speaks as the author becomes suspect.

The suspicion must intensify when the issue of race or ethnicity is introduced. For the ethnic American, like the black American, inevitably feels at odds with Anglo-American society, and is plagued by the disturbing awareness of his own otherness, the phenomenon W. E. B. Du Bois termed "double consciousness:" the peculiar sensation [...] of always looking at one's self through the eyes of others, of measuring one's soul by the tape 
of a world that looks on in amuse contempt and pity. (8) Defined by the status quo as inferior other, the self becomes, in Du Bois's words, "two souls, two thoughts, two unreconciled strivings, two warring ideals in one... body" (8-9). Emerging as it does from the collision of the Black or ethnic American's heightened sense of his own humanity with the middle and upper classes' diminished sense of it, double consciousness may be regarded as the product of what Mikhail Bakhtin calls "heteroglossia," the ever-present tension among ideas, values, and beliefs within a society, reflected in the dynamic of its language.

According to Bakhtin, the constant give-and-take over all kinds of social, political, and ethical issues ideologically charges or energizes language, as collision of one word with another, opposing word on the same topic generates dialogical relations between words and their referents as objects, and between words themselves. As Bakhtin puts it:

any concrete discourse (utterance) finds the object at which it was directed already as it were overlain with qualifications, open to dispute, charged with value, already enveloped in an obscuring mist--or, on the contrary, by the light of alien words that have already been spoken about it. It is entangled, shot through with shared thoughts, points of view, alien value judgements and accents. The word, directed toward its object, enters a dialogically agitated and tension-filled environment of alien words, value judgements and accents, weaves in and out of complex interrelationships, merges with some, recoils from others, intersects with yet a third group; and all this may crucially shape discourse, may leave a trace in all its semantic layers, may complicate its expression and influence its entire stylistic profile. ("Discourse" 276)

For the Black or the ethnic American, perhaps no realm of discourse is more "dialogically agitated and 
tension-filled" than that pertaining to his or her racial or ethnic background; and as a referent within America's "heteroglot" arena of racial and ethnic discourse, the Black or the ethnic American must inevitably confront double consciousness, the dialogical sense of self defined as "other."

Yet, if the Black or the ethnic American is the victim of double consciousness, he is, as the writer, its beneficiary, for it provides a species of inspiration. As Werner Sollors notes, this conflict within ethnic consciousness prompts ethnic writers to engage their audiences in all sorts of literary and rhetorical games:

Double consciousness, far from stifling American ethnic authors, alerts them to the possibilities of playfulness in establishing their voice. Raising and thwarting initiation expectations, feeding the gullibility of readers and then pulling the rug from under their feet, or ironically undercutting the image of a presumably stable relationship between in-group and out-group are among the weapons in the rich arsenal of ethnic writers. (252)

When relations between writer and audience become as tenuous and shifty as this, the writer's selfportrayal becomes particularly suspect. If, as suggested earlier, the autobiographical "I" must always be taken with several grains of salt, perhaps the ethnic writer's autobiographical "I" must be taken with several pounds, because double consciousness will prompt the ethnic writer to don various guises, to speak in various voices. He will, in Sollors' words, "put on the ethnic costume here, sound an American voice there. Writer, narrator, or character may begin to resemble a 'chameleon,' a crucial term in ethnic discourse" (251). In adopting multiple guises, speaking in multiple voices, the ethnic writer makes his text and his self-representation, as Bakhtin would term it, "polyvocal" and "dialogical." The victim/ 
beneficiary of double consciousness takes "heteroglot" ethnic discourse and turns its dialogicality to his own ends-he creates for himself a persona or personae for articulating his shifting narrative and ideological stances.

These stratagems became second nature to Jacob Riis. In his twelve years of police reporting previous to publishing Other Half, the Danish immigrant learned the rhetorical tricks of the documentary/autobiographical/ ethnic trade which Stott, Deman, Sollors, and Bakhtin describe. Such a speaker, lacing monologic, "authoritative" discourse with dialogic assertions of ethnic double consciousness, is indeed "contradictory." Nevertheless, as we have seen, many scholars have taken the monologic, authoritative facets of the Riis persona to be dominant. They would agree with Gandal's assertion that Riis, in his books and lectures, speaks simply "as a member of the professional middle class" (144 note 19). Yet this argument denies any influence to Riis' Danish heritage or to his twenty years' immigrant experience previous to the appearance of Other Half, six of which were spent in the same brutal poverty faced by many newly arrived. This is, nevertheless, the position that Professor Gandal, explicitly, and others, implicitly, have taken: "Riis's immigrant status and initial poverty in America should not cloud the issue," Gandal proclaims; "by the time he produced his books, he was no longer a part of the lower-class socioethnic community which he passed through [...]" (144 note 19). In terms of socioeconomic fact, the assertion is certainly true; if read in terms of the experiences' psychological and ideological impact on Riis, it is highly tenuous.

No one can deny that How the Other Half Lives of ten mimics the prevailing middle- and upper-class tendencies to exoticize the tenements or to demonize them, to make them gamily alluring dens of iniquity or dangerous nests of moral and political anarchy, or both. In these assertions of the status quo, Riis' persona becomes the voice for Bakhtin's "authoritative discourse"; that is, the 
assertion of "authority as such, or the authoritativeness of tradition, of generally acknowledged truths, of the official line and other similar authorities ("Discourse" 344). In the lines that follow, describing the social and political unrest smouldering in the tenements, the speaker's alliance with the economic and legal authority of the middle- and upper-classes and his detachment from the tenements seems complete:

Crowding all the lower ward, wherever business leaves a foot of ground unclaimed, strung along both rivers, like ball and chain tied to the foot of every street, and filling Harlem with their restless pent-up multitudes, they [the tenements] hold in their clutch the wealth and business of New York, hold them at their mercy in the day of mob-rule and wrath. The bullet-proof shutters, the stacks of hand-grenades, and the Gatling guns of the Sub-Treasury are tacit admissions of the fact, and of the quality of mercy expected. (Other Half 177)

Here the speaker's concern with maintaining the social, political, and economic power of his polite audience appears straightforward, unabashed ; he sounds as alarmed at the impending apocalypse, "the day of mob-rule and wrath," as he wishes his middle- and upper-class readers to be.

Authoritative discourse such as this is ever present in Other Half. But, over the course of the text, the speaker's relations to it become highly malleable. He may, as in the above passage, embrace it completely; or he may adopt a distanced, neutral stance. He may even oppose authority outright-or he may blend various stances. Such rhetorical tricks derive from the double consciousness Riis himself acquired in struggling with his own conflicted situation as an immigrant who became a journalist covering immigrants for the "natives." Discovering what could and could not be said, at least explicitly, to an American audience 
would draw Riis to engage in these species of rhetorical gamesmanship: if one could not protest overtly, one could embed protest within apparent accommodation. This discovery provided the foundation for Riis' rhetorical strategies, and it was the fundamental lesson he offered to a young cub reporter named Lincoln Steffens. ${ }^{3}$ Guiding the novice through the halls of a police station full of Jewish strikers whom the authorities had beaten and arrested, immigrants whose plight the city newspapers refused to address honestly, the veteran revealed how double consciousness can lead to rhetorical tricks:

'I'll tell you what to do while you are learning our ways up here; you hang around this office every morning, watch the broken heads brought in, and as the prisoners are discharged, ask them for their stories. No paper will print them, but you yourself might as well see and hear how strikes are broken by the police.' (Steffens 206-207; emphasis mine)

If newspapers will not step beyond the boundaries of authoritative discourse in their portrayals of the immigrant, then the journalist seeking to protest is obliged to operate somehow within it: to manipulate it, twist it, to employ it ironically.

In playing off of authoritative discourse in these various fashions, Riis' persona engages in the type of expression Bakhtin terms "hybrid construction." This is an utterance that belongs, by its grammatical (syntactic) and compositional markers to a single speaker, but that actually contains mixed within it two utterances, two speech manners, two styles, two 'languages,' two semantic and axiological belief systems[....T]here is no formal--compositional and syntactic--boundary between these utterances, styles, languages, belief systems; the division of voices and languages takes place within the limits of a single syntactic whole, often within the limits of a single sentence ("Discourse" 304-305). 
Such "hybridization" enables Riis, as ethnic writer, to employ the "authoritative" discourse his polite readers accept, but to manipulate it so that he may, to employ another of Bakhtin's terms, "refract" his own particular meaning. In other words, Riis' speaker adopts the assumptions, values, beliefs, and above all, the discourse of his middle- and upper-class audience, but he does so to, in Bakhtin's words, "speak indirectly, in a refracted way" ("Discourse" 327). As Bakhtin explains the concept, "refraction" enables the prose writer to employ discourses that are in varying degrees "alien" to him, for the sake of expressing his own ideas:

[A] prose writer can distance himself from the language of his own work[...]. He can make use of language without wholly giving himself up to it, he may treat it as semi-alien or completely alien to himself, while compelling language to serve all his own intentions. The author does not speak in a given language (from which he distances himself to a greater or (esser degree), but he speaks, as it were, through language, a language that has somehow more or less materialized, become, objectivized, that he merely ventriloquates[...].The prose writer makes use of words that are already populated with social interactions of others and compels them to serve his own new intentions, to serve a second master. Therefore the intentions of the prose writer are refracted, and refracted at different angles depending on the degree to which the refracted, heteroglot languages he deals with are socially-ideologically alien, already embodied and already objectivized. ("Discourse” 299-300)

Refraction, then, creates a quality of "doublevoicedness" in prose, as the writer's intentions, embedded in the particular discourse he employs, emerge and compete with those implicit in that discourse. In ethnic writing like Riis', such effects as refraction and double- 
voicedness are products of double-consciousness, of the writer's sense of himself as socially-defined Other, and are in large part responsible for the "chameleon"-like quality which Sollors finds in so much ethnic writing (25).

Throughout How the Other Half Lives, Riis' persona constantly changes his colors. In the passage that follows, the speaker, with the same air of "authoritative" condescension he adopts in the previous excerpt, describes a Chinatown "Joss House," a temple for the worship of Joss, a Chinese deity, which serves also as a communal gaming hall. With heavy irony, the speaker compliments the pragmatism of "these people" in so conveniently blending their desires for salvation and prosperity--but then he abruptly broadens his criticism:

The practical way in which these people combine worship with business is certainly admirable. I was told that the scrawl covering the wall of both sides of a shrine stood for the names of the pillars of the church or club--the Joss House is both--that they might have their reward in this world, no matter what happened to them in the next. There was another inscription overhead that needed no interpreter. In familiar English letters, copied bodily from the trade dollar, was the sentiment: "In God We Trust." The priest pointed to it with undisguised pride and attempted an explanation, from which I gathered that the inscription was intended as a diplomatic courtesy, a delicate international compliment to the "Melican Joss," the almighty dollar. (Other Half 82)

As the speaker shifts his irony from Chinese greed to American greed, the reader may sense that this speaker is indeed double-voiced, chameleon-like: rhetorically, the passage virtually turns back upon itself. By juxtaposing Chinese temples with worldly inscriptions to American currency with devotional ones, the persona comes to the brink of criticizing the American devotion to getting 
ahead. But he "refracts" his irony--that is, softens and diverts it--by focusing on the Chinese priest: he, not the speaker, characterizes the dollar as " "the Melican Joss," " though the perceptive reader senses that the speaker and the author agree. In this instance, one finds Riis' persona willing, even eager, to tamper with the seemingly simple relations, reflected in the previous excerpt, between speaker and subject and between speaker and audience.

Even when he addresses his readers directly, Riis' chameleon-like speaker, spurred by double consciousness, can abruptly change his color. While the "I" may parrot his middle-class audience's assumptions about the immigrant, he will also chide them for ignorance and lack of experience; he may show his readers the dehumanizing effects of the immigrant's surrender to the authoritative discourse many of them accept, then challenge them to engage in double consciousness themselves. Here, the speaker, conducting his audience on a "slumming" tour, draws them up the stairs of a dark and stifling tenement, thrusts them into a heartbreaking domestic scene, then turns on them with an uncomfortable question:

Here is a door. Listen! That short hacking cough, that tiny, helpless wail--what do they mean? They mean that the soiled bow of white you saw on the door downstairs will have another story to tell--Oh! A sadly familiar story--before the day is at an end. The child is dying with measles. With half a chance, it might have lived; but it had none. That dark bedroom killed it. 'It was took all of a suddint,' says the mother, smoothing the throbbing little body with trembling hands. There is no unkindness in the rough voice of the man in the jumper, who sits by the window grimly smoking a clay pipe, with the little life ebbing out of his sight, bitter as his words sound: 'Hush, Mary! If we cannot keep the baby, need we complain-such as we?' Such as we. What if the words ring in your ears as we grope our way up the stairs and down from 
floor to floor, listening to the sounds behind the closed doors-some of quarreling, some of coarse songs, more of profanity. They are true. (Other Half 38)

The episode is calculated to elicit the emotion of the audience, then to strike at its conscience via its consciousness. The details of the event--measles, dark bedroom, the homely dignity of the parents' words; all cast in the present tense to heighten the reader's sense of "documentary" fact--skillfully address the Victorian reverence for childhood, motherhood, and sentiment. The persona, with his interjection of "Oh! a sadly familiar story," conveys his own brief surrender to feeling.

Yet he remains sufficiently removed from the scene, from his own emotion, and from his audience to employ the episode to refract his and the author's intentions. In echoing the words of the dying baby's father, the speaker shifts his rhetorical stance from sentimental involvement in the scene to detachment from it and from his readers. The persona notes that "there is no unkindness in [the father's] rough voice"; nevertheless, to the speaker, the father's words "such as we" sound "bitter." The discrepancy signals the assertion of rhetorical distance: if the father accepts his family's degradation as members of the "other half," the persona does not. The father speaks from a single consciousness: his "such as we" represents his tacit but complete surrender to the forces controlling tenement life: poverty, unhealthy living conditions, and, above all, the social and economic power of the polite classes. Overcome by these obstacles the father abandons his own, heightened sense of the humanity of his family and himself: his "such as we" means that, in his eyes, he, his wife, and their children are become the inferior creatures the polite classes assume them to be. It is a lament at this enforced inferiority, offered with no irony, with "no unkindness," and parents and child emerge as virtuous victims.

Nevertheless, the speaker senses "bitterness" in the 
father's words--because they speak to the bitter conflict within his own double consciousness and in that of his creator. Thus, when he repeats the father's words, the speaker's " "such as we" " is laced with irony and protest; if the father has surrendered his own double consciousness, the speaker has not. In turning to his readers, wondering if the father's words "may ring in your ears" (emphasis mine) as they have rung in his, the speaker also turns on his readers, chiding and challenging them. If the father's words were to ring in the ears of the audience, it would be for the first time; the fact that it has not happened previously emphasizes the genteel classes' lack of awareness of and concern for the human plight of the ethnic urban poor. Yet, in posing the possibility that it might happen, the persona challenges his audience to engage in double consciousness themselves, to confront the contradictions between their own "authoritative" assumptions about the ethnic tenement poor and the simple dignity of the decent folk portrayed here.

Riis' speaker turns to and on his audience periodically, becoming more aggressive in his efforts to rouse double consciousness in them. In the passage that follows, the persona urges his readers to put aside their preconceptions and to experience firsthand not merely the grim conditions of the tenement, but the psychology of the tenement dwellers--in other words, to enter their minds and hearts.

Go into any of the respectable tenement neighborhoods [...] where live the great body of hard-working Irish and German immigrants and their descendants, who accept naturally the conditions of tenement life, because for them there is nothing else in New York; be with and among its people until you understand their ways, their aims, and the quality of their ambitions, and unless you can content yourself with the scriptural promise that the poor we shall always have with us, or with the menagerie view that if fed, they have no 
cause for complaint, you shall come away agreeing with me that, humanly speaking, life there does not seem worth living. (Other Half 122-123)

In pointing up the opposition between "authoritative" conceptions which dismiss or demean the ethnic poor ("the scriptural promise," "the menagerie view") and those which affirm the tenement dwellers' complex, individual humanity (their "ways," their "aims," and "the quality of their ambitions"), the speaker again thrusts the burden of double consciousness onto his audience. Acknowledging his own sympathies for the psychological view of the tenement dwellers, ${ }^{4}$ he comes to the brink of accusing his audience of subscribing to the scriptural or the menagerie view--but stops short by couching the idea in the subjunctive--"unless you can content yourself[...]" (emphasis mine). Riis, the immigrant journalist who knows what can and cannot be said to "native" readers, is content to leave persona and readers poised on their respective sides of the threshold.

Such brinksmanship may seem "wildly contradictory, morally schizophrenic," but it is, above all else, rhetorically and ideologically subversive, and "chameleon-like": rhetorical doubleness reflects--or, as Bakhtin puts it, "refracts"--ideological doubleness. Thus, in contriving this shifting and blending of voices in his speaker, Riis seeks less to confirm his assimilation into the middle class than to subvert middle- and upper-class assumptions regarding the immigrant urban poor, the same assumptions he had confronted daily since his own arrival, the same assumptions he was obliged to address in his work as police reporter.

Because of his experiences as immigrant and as immigrant journalist, Riis came to ethnic double consciousness and devised the dialogical strategies for articulating it. Immersed in what Bakhtin might well describe as the heteroglossia of ethnic relations in late $19^{\text {th }}$ century America, the Danish carpenter-cum- 
American photojournalist learned that the immigrant is not free to define himself; rather, he finds himself defined in the "authoritative discourse" of the "natives." Riis understood that, in the America of his time, the breadth and depth of the immigrant's humanity are, as DuBois puts it, "measur[ed...] by the tape of a world that looks on in amused contempt and pity" (8); that the immigrant is, to apply Bakhtin's expression, “always entangled in someone else's discourse [...] an object of dispute that is conceptualized and evaluated vicariously, inescapable from the social apperception of it" ("Discourse" 330). Knowing what could and could not be said concerning the plight of the immigrant, Riis embedded the latter within the former: he devised a persona, a rhetorical chameleon through whom he dialogically shaded and tinted authoritative discourse to "refract" his true colors.

\section{Endnotes}

1 The possibility that Riis creates a persona has been raised previously. Peter B. Hales, discussing Riis' emphasis, in Other Half and in The Making of an American, on his clumsiness as a photographer, asserts that this constitutes a pose: Riis' bumbling photographer was merely a persona. Its existence was designed to draw the audience's attention away from the manipulations of the creator and the distortions of the medium, to lull viewers into believing themselves witnesses to an unrehearsed and unstaged confrontation with the raw grit of a previously hidden world (193). In addition, I maintain that Riis manipulates every facet of his self-portrayal in order to subvert the ethnic assumptions of many middle- and upper-class readers.

2 Apparently, these "colored views" were nature scenes and historical sites. In American, Riis refers to a stereopticon slide of Heidelberg Castle as "one of my most beautiful colored views" (185).

3 I make this same point about the Steffens passage in a previous article on Riis: "Walking the Ethnic Tightwire: Ethnicity and Dialectic in Jacob Riis's How the Other Half Lives." Journal 
of American Culture 20 (1997): 41-53. For a contrasting viewpoint on Steffens' comment and Riis, see Christopher Carter's "Writing With Light: Jacob Riis' Ambivalent Exposures." College English 71 (2008): 117-141.

4 Gandal offers an enlightening discussion of Riis' place in the development of tenement psychology (91-9).

\section{Works Cited}

Adell, Sandra. Double Consciousness/Double Bind:

Theoretical Issues in Twentieth-Century Black

Literature. Urbana: U of Illinois P, 1994.

Bakhtin, Mikhail. "Discourse in the Novel." The Dialogic Imagination: Four Essays. Trans. Caryl Emerson and Michael Holquist. Ed. Michael Holquist. Austin: $U$ of Texas P., 1981. 259-422.

Buk-Swienty, Tom. The Other Half: The Life of Jacob Riis and the World of Immigrant America. Trans. Annette Buk-Swienty. New York: W. W. Norton and Company, 2008.

Carter, Christopher. "Writing With Light: Jacob Riis's Ambivalent Exposures." College English 71 (2008): 117-141.

de Man, Paul. "Autobiography as De-Facement." The Rhetoric of Romanticism. New York: Columbia UP, 1984. 67-81.

Du Bois, W. E. B. The Souls of Black Folk. 1903. New York: Knopf, 1993.

Gandal, Keith. The Virtues of the Vicious: Jacob Riis, Stephen Crane, and the Spectacle of the Slum. New York: Oxford UP, 1997. 
Hales, Peter B. Silver Cities: The Photography of American Urbanization, 1839-1915. Philadelphia: Temple UP, 1984.

Higham, John . Strangers in the Land: Patterns of American Nativism 1860-1925. New Brunswick, NJ: Rutgers University Press, 1955.

Jones, Maldwyn Allen. American Immigration. Chicago: The University of Chicago Press, 1960.

Lane, James B. Jacob A. Riis and the American City. Port Washington, NY: Kennikat Press, 1974.

Leviatin, David. "Framing the Poor: The Irresistibility of How the Other Half Lives." How the Other Half Lives. By Jacob A. Riis. Ed. David Leviatin. Boston: St. Martin's, 1996. 1-51.

Lubove, Roy. The Progressives and the Slums: Tenement House Reform in New York City, 1890-1917. Pittsburgh: U of Pittsburgh P, 1962.

Madison, Charles A. " Preface to the Dover Edition." How the Other Half Lives. By Jacob A. Riis. Ed. Charles A. Madison. New York: Dover Publications, Inc., 1971. v-viii.

Riis, Jacob A. A Ten Years' War: An Account of the Battle with the Slum in New York. 1900. New York: Books for Libraries Press, 1969.

---. How the Other Half Lives. 1890. New York: Dover: Publications, Inc., 1971.

---. The Making of an American. 1901. New York: MacMillan, 1924. 
Sollors, Werner. Beyond Ethnicity: Consent and Descent in American Culture. New York: Oxford UP, 1986.

Stange, Maren. Symbols of Ideal Life: Social

Documentary Photography in America 1890-1950.

Cambridge: Cambridge UP, 1989.

Steffens, Lincoln. The Autobiography of Lincoln

Steffens. New York: Harcourt, Brace, 1931.

Stein, Sally. "Making Connections with the Camera:

Photography and Social Mobility in the Career of Jacob Riis." Afterimage. May, 1983. 9-16.

Stott, William. Documentary Expression and Thirties America. New York: Oxford University Press. 1973.

Ware, Louise. Jacob A. Riis: Police Reporter, Reformer, Useful Citizen. New York: D. Appleton-Century Company, 1938.

Yochelson, Bonnie, and Daniel Czitrom. "Introduction." Rediscovering Jacob Riis: Exposure Journalism and Photography in Turn-of-the-Century New York. By Yochelson and Czitrom New York: The New Press, 2007. 